\title{
OPTIMASI PROTEIN DAN TOTAL PADATAN TERLARUT DALAM EKSTRAK \\ CACING TANAH (Lumbricus rubellus) \\ [Optimization of Protein and Total Soluble Solids in Earthworm \\ (Lumbricus rubellus) Extract]
}

\author{
Nur Hidayat", Siti Aminah dan Nur Lailatul Rahmah \\ Departemen Teknologi Industri Pertanian, Universitas Brawijaya, \\ Jl. Veteran Malang 65145 \\ *Email korespondensi: nhidayat@ub.ac.id
}

Diterima : 13 Juni 2017

Disetujui : 30 Januari 2018

\begin{abstract}
This study aimed to obtain N-Amino and Total Soluble Solids (TSS) in the earthworms extract. The material used was earthworm type Lumbricus rubellus with age about 40 days. The design used in this study was Response Surface Methods (RSM) with the Central Composite Design, consisting of two factors: the incubation time (2, 4, and 6 days) and the percentage of basic material $(10,15$, and $20 \%(\mathrm{w} / \mathrm{v}))$. This research was conducted by incubating earthworm juice with $4 \%(\mathrm{w} / \mathrm{v}) \mathrm{NaCl}$ solution in accordance with treatment of incubation time and percentage of basic material. The results showed that the optimal results obtained were soluble protein $7.51 \%(\mathrm{w} / \mathrm{v})$ and TPT $48.90 \%(\mathrm{w} / \mathrm{v})$ using 2 days incubation time and $15 \%(\mathrm{w} / \mathrm{v})$ earthworms.
\end{abstract}

Keywords: earthworm, nutrition, RSM, incubation time

\begin{abstract}
ABSTRAK
Penelitian ini bertujuan untuk mendapatkan N-Amino dan Total Padatan Terlarut (TPT) dalam ekstrak cacing tanah. Bahan yang digunakan adalah cacing tanah jenis Lumbricus rubellus dengan umur sekitar 40 hari. Rancangan yang digunakan dalam penelitian ini adalah Response Surface Methods (RSM) dengan rancangan Desain Komposit Terpusat, terdiri dari dua faktor yaitu waktu inkubasi (2, 4, dan 6 hari) dan persentase bahan dasar (cacing tanah) $(10,15$, dan $20 \%$ (b/v)). Penelitian ini dilakukan dengan menginkubasikan jus cacing tanah dengan larutan $\mathrm{NaCl} 4 \%(\mathrm{~b} / \mathrm{v})$ sesuai dengan perlakuan waktu inkubasi dan persentase bahan dasar. Hasil penelitian menunjukkan bahwa hasil optimal yang diperoleh adalah protein terlarut 7,51\% (b/v) dan TPT 48,90\% (b/v) menggunakan waktu inkubasi 2 hari dan cacing tanah $15 \%(\mathrm{~b} / \mathrm{v})$.
\end{abstract}

Kata kunci: cacing tanah, nutrisi, RSM, waktu inkubasi

\section{PENDAHULUAN}

Cacing tanah adalah hewan yang tidak memiliki tulang belakang dan mengandung protein sebesar 64-76\% (Maulida, 2015), lemak (7-10\%), kalsium $(0,55 \%)$, fosfor $(1 \%)$, dan serat kasar $(1,08 \%)$ (Palungkun, 2010). Jumlah produksi cacing tanah di Indonesia sekitar puluhan ton dan terus meningkat untuk memenuhi permintaan pasar (Palungkun, 2010). Salah satu kota yang terdapat peternakan cacing tanah adalah Malang. Namun pemanfaatan cacing tanah masih sebatas pakan ternak, obat, kosmetik, penghasil pupuk organik, dan makanan konsumsi manusia. Padahal hasil penelitian Julendra dan Sofyan (2007) menunjukkan bahwa ekstrak protein 
cacing tanah mempunyai daya antibakteri yang mampu menghambat pertumbuhan bakteri E. coli.

Secara umum, ekstrak protein didapatkan melalui proses ekstraksi. Beberapa contoh proses ekstraksi, yaitu zat kimia (Shen et al., 2015), ultrasonik (Benndorf et al., 2009), inkubasi aerob dan anaerob. Namun, beberapa metode tersebut memiliki kelemahan sehingga Soeka et al. (2008) lebih menyarankan ekstraksi anaerob karena inkubasi anaerob mengandalkan aktivitas dari mikroorganisme sehingga dapat menghemat biaya operasional. Hal tersebut juga didukung oleh pendapat Prabha et al. (2014) yang menyebutkan bahwa di dalam usus cacing tanah ditemukan mikroorganisme yang bersifat anaerob fakultatif. Adanya inkubasi memberikan kesempatan pada mikroorganisme di cacing tanah untuk tumbuh dan memecah senyawa-senyawa sehingga diharapkan dapat membantu dalam pelarutan protein cacing tanah. Maka dipilih metode pelarutan protein secara anaerob atau anaerob fakultatif.

Untuk mendapatkan ekstrak protein yang optimal maka perlu dikendalikan faktor-faktor yang berkaitan, yaitu waktu inkubasi dan persentase bahan dasar (cacing tanah). Semakin lama waktu inkubasi maka kesempatan mikroorganisme untuk beraktivitas dan memecah protein semakin tinggi. Berdasarkan hasil penelitian Shao et al. (2013), waktu inkubasi memberikan hubungan terhadap hasil kelarutan berupa pola naik turunnya ekstrak. Kemudian, jumlah bahan dasar yang digunakan juga dapat memberikan peran terhadap jumlah kandungan/komponen di dalam suatu larutan. Semakin banyak penggunaan bahan memungkinkan semakin banyak kandungan protein yang terakumulasi kemudian terpecah. Untuk menghasilkan N-Amino dan TPT optimal maka perlu menggunakan penelitian terdahulu. Pada penelitian Desi et al. (2016), pelarutan alkaloid dari cacing tanah dapat dilakukan dengan waktu inkubasi 3 hari. Pada penelitian Sutama et al. (2015), pembuatan biosuplemen dari fermentasi cacing tanah menggunakan 10, 20, 30, dan $40 \%$ cacing tanah dan didapatkan protein terlarut tertinggi pada $30 \%$. Berdasarkan uraian tersebut maka perlu dilakukan penelitian untuk dapat menghasilkan $\mathrm{N}$ amino dan TPT yang optimal dengan menggunakan faktor waktu inkubasi dan persentase bahan dasar yang tepat.

\section{BAHAN DAN METODE}

\section{Alat dan Bahan}

Alat-alat yang digunakan meliputi toples, Beaker glass, blender, timbangan, gelas ukur, tabung reaksi, cawan plastik, dan spatula. Alat yang digunakan dalam analisis adalah Elenmeyer, oven, cawan, gelas ukur, dan beberapa glassware.

Bahan yang digunakan dalam penelitian ini adalah cacing tanah yang berasal dari Dusun Krajan Desa Gading Kulon Kecamatan Dau Kabupaten Malang, aquades dan garam. Bahan analisis yang dibutuhkan adalah alkohol etanol 70\%, kertas saring Whatman no 41, desikator larutan PP 1\%, NaOH (teknis), dan formaldehid $40 \%$.

\section{Metode Penelitian}

\section{Alur Penelitian}

Penelitian diawali dengan menyiapkan bahan baku, kemudian proses pelarutan secara anaerob. Sebelum reaktor dikondisikan anaerob maka diambil sampel untuk uji $\mathrm{N}$-formol dan TPT. Setelah proses inkubasi anaerob, maka dilakukan uji N-formol dan TPT. 


\section{Rancangan Perobaan}

Rancangan percobaan yang digunakan adalah Respon Surface Methods (RSM) dengan Rancangan
Komposit Terpusat dengan menggunakan 2 faktor, yaitu waktu inkubasi $(2,4$, dan 6 hari) dan persentase bahan cacing tanah (10, 15, dan 20\% (b/v)). Rancangan percobaan dilakukan seperti Tabel 1.

Tabel 1. Rancangan Percobaan

\begin{tabular}{ccc}
\hline \multirow{2}{*}{ No } & \multicolumn{3}{c}{ Variabel Asli } \\
\cline { 2 - 3 } & A= Waktu (Hari) & B= Cacing Tanah $(\%)(\mathrm{b} / \mathrm{v})$ \\
\hline 1 & 1 & 15 \\
2 & 2 & 10 \\
3 & 2 & 20 \\
4 & 4 & 8 \\
5 & 4 & 22 \\
6 & 4 & 15 \\
7 & 4 & 15 \\
8 & 4 & 15 \\
9 & 4 & 15 \\
10 & 4 & 15 \\
11 & 6 & 10 \\
12 & 6 & 20 \\
13 & 7 & 15 \\
\hline
\end{tabular}

\section{Prosedur Analisis}

a. Protein terlarut

Uji protein terlarut dilakukan melalui titrasi formol standar AOAC (2005). Perhitungan \% N menggunakan rumus (Hafiluddin et al., 2014):

$\% \mathrm{~N}=\frac{\text { (titrasi ) } \times \mathrm{N} \mathrm{NaOH} \times 14,008}{\text { berat bahan } \times 10} \times 100 \%$ (3)

Keterangan :

Titrasi $=\mathrm{NaOH}$ sampel - blanko

$\mathrm{N} \mathrm{NaOH}=0.1 \mathrm{~N}$

Berat bahan untuk uji $(\mathrm{g})$

\section{b. Uji TPT}

Uji TPT dilakukan mengikuti prosedur BSN (2005). Perhitungan nilai TPT menggunakan rumus sebagai berikut:
Keterangan

$\mathrm{A}=$ berat cawan (gram)

$\mathrm{B}=$ berat kering cawan + isi (gram)

$\mathrm{V}$ bahan $=$ Vol bahan contoh $(\mathrm{mL})$

\section{Analisis data}

Pengolahan data dilakukan dengan menggunakan Design Expert 7.0. Data dimasukkan dalam rancangan komposit terpusat dengan dua faktor. Kemudian respon yang digunakan $\mathrm{N}$-amino dan total padatan terlarut.

\section{HASIL DAN PEMBAHASAN}

\section{Respon Protein Terlarut pada Ekstrak Cacing Tanah}

Hasil protein terlarut dapat dilihat pada Gambar 1.

$\operatorname{TPT}(\mathrm{g} / \mathrm{L})=\frac{(b-\mathrm{a}) \times 1000}{\mathrm{~V} \text { Bahan }}$ 


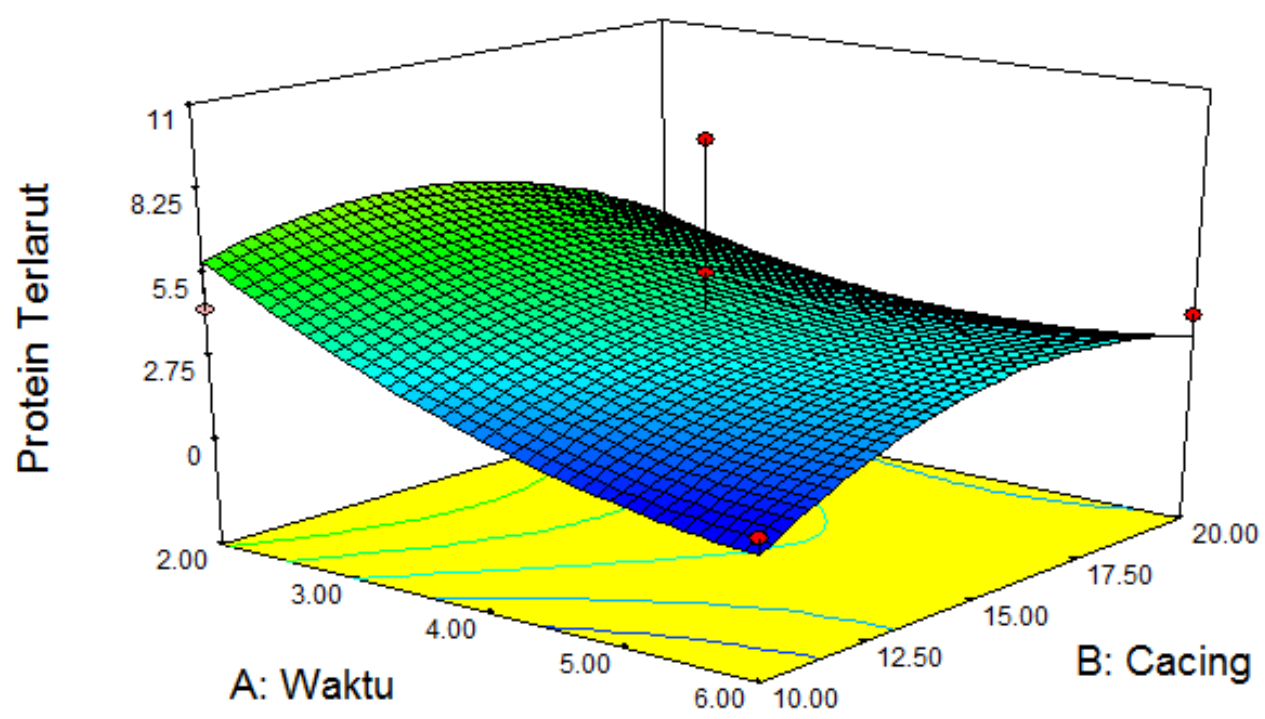

Gambar 1. Hubungan waktu inkubasi dan jus cacing dengan protein terlarut

Hasil penelitian menunjukkan bahwa peningkatan waktu inkubasi tidak meningkatkan protein terlarut (not significant). Diduga hal tersebut berkaitan dengan keberadaan mikroorganisme pada cacing tanah. Menurut Aminudin dan Inayati (2009), mikroorganisme membutuhkan sumber makanan yang mengandung $\mathrm{C}, \mathrm{H}, \mathrm{O}, \mathrm{N}$, yang dapat diambil dalam bentuk protein dan karbohidrat untuk pertumbuhannya. Hal tersebut didukung oleh hasil penelitian Putra et al. (2015), bahwa di dalam cacing tanah L. rubellus ditemukan adanya bakteri selulolitik, amilolitik, proteolitik, dan fungi. Singleton et al. (2003) bahkan menegaskan bahwa pada $L$. rubellus ditemukan adanya beberapa bakteri yaitu Acidobacteria, Actinobacteria, Paenibacillus sp, dan Pseudomonas sp. Maka memungkinkan sebagian protein dipecah dan digunakan bakteri yang ada untuk pertumbuhannya sehingga jumlah protein terlarut relatif tetap.

Jika dikaitkan dengan protein maka penelitian ini sesuai dengan hasil penelitian Sutama et al. (2015), yaitu penggunaan variasi persentase bahan cacing tanah tidak meningkatkan nilai protein terlarut yang signifikan atau beda nyata. Semakin banyak penggunaan bahan seharusnya semakin banyak kandungan protein yang terakumulasi kemudian terpecah namun dalam kenyataannya saat pelarutan tidak memberikan nilai beda nyata pada masing-masing variasi persentase bahan dasar (cacing tanah). Hasil penelitian Safitri dan Swarastuti (2016), menunjukkan bahwa semakin tinggi bahan maka semakin tinggi total mikrobanya akibat dari sifat bahan yang dapat digunakan dalam pertumbuhannya. Pada penelitian ini menggunakan persentase bahan dasar (cacing tanah) sebesar 10, 15, dan $20 \% \quad(\mathrm{~b} / \mathrm{v})$. Penggunaan persentase cacing tersebut yang semakin meningkat mengakibatkan jumlah akumulasi mikroorganisme yang telah ada di dalam larutan cacing menjadi semakin meningkat. Jumlah mikroorganisme yang semakin meningkat menyebabkan kebutuhan substrat untuk metabolismenya juga meningkat. 


\section{Respon TPT pada Ekstrak Cacing \\ Tanah}

Hasil pengujian TPT dapat dilihat pada Gambar 2

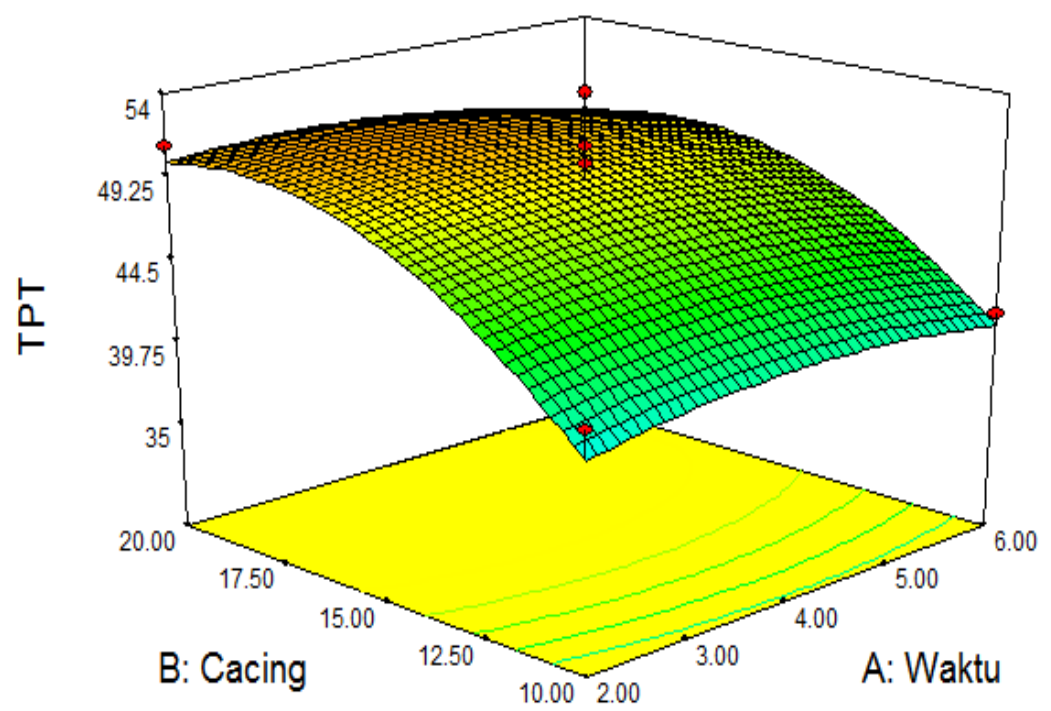

Gambar 2. Hubungan waktu inkubasi dan jus cacing dengan TPT

Berdasarkan hasil penelitian, dapat diketahui bahwa semakin tinggi persentase cacing tanah yang digunakan maka semakin tinggi TPT yang didapatkan. Menurut Kumalasari et al. (2015), semakin banyak bahan yang digunakan maka total padatan terlarut semakin tinggi. Berdasarkan hasil penelitian Lourdumary dan Uma (2012), tepung cacing tanah mengandung karbohidrat, protein, nitrogen, phospor, potasium, besi, magnesium, mangan, seng, tembaga, dan kalsium. Maka beberapa komponen padatan terlarut dalam ekstrak cacing tanah yaitu protein, karbohidrat, kalsium, phospor, dan besi. Jika dikaitkan dengan keberadaan mikroorganisme dalam larutan yang menggunakan protein untuk metabolismenya, maka diduga penambahan TPT akibat aktivitas metabolisme mikroorganisme tersebut. Menurut Retnowati dan Joni (2014), sisa total gula, asam laktat dan asam organik yang terbentuk dari metabolisme mikroba dapat dihitung sebagai TPT. Pada penelitian ini tingginya TPT lebih disebabkan kenaikan bahan atau senyawa selain protein karena hasil penelitian $\mathrm{N}$ amino memiliki pola konstan sehingga peningkatan TPT bukan disebabkan oleh protein.

Berdasarkan hasil penelitian, dapat diketahui bahwa hubungan waktu inkubasi dan hasil TPT adalah tidak signifikan. Semakin lama waktu inkubasi maka nilai TPT yang didapatkan tidak berubah. Hal tersebut kemungkinan disebabkan karena penggunaan senyawa-senyawa larut air oleh mikroorganisme. Penelitian Napitupulu et al. (2015), menunjukkan bahwa total padatan terlarut menurun seiring tingginya konsentrasi gula dan lama fermentasi. Hal tersebut disebabkan karena semakin tinggi konsentrasi gula 
dan lama fermentasi dapat menghasilkan mikroba yang banyak pada bahan. Menurut Nendissa et al. (2015), selama waktu fermentasi mikroorganisme yang ada memanfaatkan substrat dalam suatu bahan untuk proses metabolismenya sehingga nilai total padatan terlarut semakin menurun. Maksudnya, substrat tersebut yang tergolong TPT justru digunakan oleh mikroorganisme untuk pertumbuhannya sehingga jumlah subtrat tersebut semakin menurun maka jika dianalisis kandungan TPT menunjukkan penurunan.

\section{Optimasi Respon $\mathbf{N}$-amino dan TPT}

Pada optimasi dibutuhkan standar batasan faktor dan respon dari penelitian dan literatur yang serupa. Batasanbatasan tersebut dimasukkan ke dalam komputasi dengan menyertakan tujuan terhadap faktor dan respon, yaitu minimal untuk waktu inkubasi, target $15 \%$ untuk bahan dasar, maksimal untuk protein terlarut dan TPT. Selanjutnya dapat diperoleh solusi optimal seperti pada Tabel 1.

Tabel 1. Solusi Hasil Optimasi

\begin{tabular}{lr}
\hline \multicolumn{1}{c}{ Parameter } & Standar Prediksi \\
\hline Waktu Inkubasi (hari) & 2,00 \\
Bahan Dasar (\%) (b/v) & 15,00 \\
Protein terlarut (\%) (b/v) & 7,51 \\
TPT (\%) (b/v) & 48,90 \\
Ketepatan (desirability) & 0,77 \\
Keterangan & Selected \\
\hline
\end{tabular}

Hasil tersebut merupakan hasil matematis dari model yang diperoleh berdasarkan data. Waktu inkubasi dan bahan dasar diatur pada kondisi kisaran percobaan, sedanngkan hasil pada kondisi maksimum. Jumlah protein terlarut dan total padatan terlarut belum pernah dilaporkan pada penelitian-peneltian sebelumnya. Nilai ketepatan hasil mencapai 0,77. Nilai ini masih kurang baik karena di bawah 0,95. Hal ini kemungkinan disebabkan adanya senyawa semacam buih yang terdapat dalam jus cacing sehingga sampling yang dilakukan belum dapat memberikan hasil yang optimal. Namun demkian, ekstrak ini menunjukkan hasil yang baik bagi pertumbuhan bakteri (Hidayat, et al., 2017).

\section{KESIMPULAN}

Hasil penelitian menunjukkan bahwa optimasi hasil optimal yang diperoleh adalah protein terlarut 7,51\% (b/v) dan TPT 48,90\% (b/v) dengan waktu inkubasi 2 hari dan cacing tanah 15\% $(\mathrm{b} / \mathrm{v})$.

\section{Ucapan Terima Kasih}

Terima kasih kepada Fakultas Teknologi Pertanian Universitas Brawijaya atas pendanaan yang telah diberikan sehingga penelitian dapat dilakukan.

\section{DAFTAR PUSTAKA}

Aminudin, M. dan I. Habib. 2009. Pengaruh lamanya penyimpanan terhadap pertumbuhan bakteri pada nasi yang dimasak di rice cooker 
dengan nasi yang dikukus. J. Mutiara Medika. 9(2):18-22.

AOAC. 2005. Official Methods of Analysis. Association of Official Analytical Chemists. Virginia.

Benndorf, D., C. Vogt, N. Jehmlich, Y. Schmidt, H. Thomas, G. Woffendin, A. Shevchenko, H.H. Richnow, and M.V. Bergen. 2009. Improving protein extraction and separation methods for investigating the metaproteome of anaerobic benzene communities within sediments. J. Biodegredation. 20(6):737-750.

BSN. 2005. Cara Uji Kadar Padatan Terlarut Total secara Gravimetri SNI 06-6989.27-2005. Badan Standardisasi Nasional. Jakarta.

Desi, I. R. 2016. Isolasi dan Karakterisasi Senyawa Alkaloid dari Cacing Tanah (Lumbricus rubellus Hoffmeister). (Skripsi). Universitas Islam Bandung. Bandung.

Hafiluddin, H., Y. Perwitasari, dan S. Budiarto. 2014. Analisis kandungan gizi dan bau lumpur ikan bandeng (Chanos chanos) dari dua lokasi yang berbeda. J. Kelautan. 7(1):3344.

Hidayat, N., Hotmartua, dan H.P. Purba. 2017. Pengaruh jus cacing tanah sebagai nutrisi pada pertumbuhan bakteri. Makalah Semnas APTA. Agustus 2017. Bengkulu.

Julendra, H. dan A. Sofyan. 2007. Uji in vitro penghambatan aktivitas escherichia coli dengan tepung cacing tanah (Lumbricus rubellus). J. Media Peternakan. 30:41-47.

Kumalasari, R., R. Ekafitri, dan D. Desnilasari. 2015. Pengaruh bahan penstabil dan perbandingan bubur buah terhadap mutu sari buah campuran pepaya-nanas. J. Hort. 25(3):266-276.

Lourdumary, A.J.B. and K. Uma. 2012. Nutrional evaluation of earthworm powder (Lampito mauritii). J. of Applied Pharmaceutical Science. 3(3):82-84.
Maulida, A. A. A. 2015. Budi Daya Cacing Tanah Unggul Ala Adam Cacing. Agromedia pustaka. Jakarta. $94 \mathrm{hlm}$.

Napitupulu, M. O. W., Setyohadi, dan L.M. Lubis. 2015. Pengaruh variasi konsentrasi gula sukrosa dan lama fermentasi terhadap pembuatan kopi kombucha. J. Rekayasa Pangan dan Pert. 3(3):316-322.

Nendissa, S. J., R. Breemer, dan N. Melamas. 2015. Pengaruh konsentrasi ragi Saccharomyces cerevisiae dan lama fermentasi terhadap kualitas cuka tomi-tomi (Flacourtia inermis). J. Teknologi Pertanian AGRITEKNO. 4(2):5055.

Palungkun, R. 2010. Usaha Ternak Cacing Tanah. Penebar Swadaya. Jakarta. $121 \mathrm{hlm}$.

Prabha, M. L., M.S. Priya., and R. Pavithra. 2014. Microorganisms in the gut of earthworm Eudrilus eugeniae. Int. J. Curr Res Chem Pharma Sci. 1(3): 6-9.

Putra, P.P.I.K, I.N.S. Sutama, dan I.M. Mudita. 2015. Kandungan nutrien dan populasi mikroba inokulan yang diproduksi dari level cacing tanah (Lumbricus rubellus) berbeda. J. Peternakan Tropika. 3(2):430442.

Retnowati, P. A. dan J. Kusnadi. 2014. Pembuatan minuman probiotik sari buah kurma (Phoenix dactylifera) dengan isolat Lactobacillus casei dan Lactobacillus plantarum. J. Pangan dan Agroindustri. 2(2): 70-81.

Safitri, M. F. dan A. Swarastuti. 2016. Kualitas kefir berdasarkan konsentrasi kefir grain. J. Aplikasi Teknologi Pangan. 2(2):87-92.

Shao, L., T. Wang, T. Li, F. Lu, and P. He. 2013. Comparison of sludge digestion under aerobic and anaerobic conditions with a focus on the degradation of proteins at mesophilic 
J. Bioresource Technology. 140:131-137.

Shen, K., J. Sun, X. Cao, D. Zhou, and J. Li. 2015. Comparison of different buffers for protein extraction from formalin-fixed and paraffinembedded tissue specimens. J. Pone. 10(11):1-13.

Singleton, D. R., P.F. Hendrix, D.C. Coleman, W.B. Whitman. 2003. Identification of uncultured bacteria tightly associated with the intestine of the earthworm Lumbricus rubellus (Lumbricidae; Oligochaeta). J. Soil Biology and Biochemistry. 35(12):1547-1555.

Soeka, Y.S., J. Sulistyo, dan D.E. Naiola. 2008. Analisis biokimia minyak kelapa hasil ekstraksi secara fermentasi. J. Biodiversitas.9:91-95.

Sutama, I. N. S., I. M. Mudita, I. W. Suberata, and N. W. Siti. 2015. Effect of dietary biosupplement fermented earthworm microbes consortium inoculant on the carcass production and cholesterol blood profile of baliness duck. J. of Research in Agriculture and Animal Science. 3:01-06. 